\title{
HUKUMAN PIDANA PENGAMBILAN PAKSA JENAZAH COVID-19 DI INDONESIA
}

\author{
Michelle Angelika S ${ }^{1}$, Yohanes Firmansyah², Hanna Wijaya ${ }^{4}$, Yana Sylvana ${ }^{3}$ \\ ${ }^{1}$ Program Studi Magister Hukum, Universitas Pembangunan Nasional Veteran Jakarta \\ Email: michelleangelika111@gmail.com \\ ${ }^{2}$ Program Studi Magister Hukum, Universitas Pembangunan Nasional Veteran Jakarta \\ Email: yohanesfirmansyah28@gmail.com \\ ${ }^{3}$ Program Studi Magister Hukum, Universitas Pembangunan Nasional Veteran Jakarta \\ Email: sylavanayana@gmail.com \\ ${ }^{4}$ Program Studi Magister Hukum, Universitas Pembangunan Nasional Veteran Jakarta \\ Email: hannwijaya@yahoo.com
}

Masuk : 05-10-2020, revisi: 06-02-2021, diterima untuk diterbitkan : 08-02-2021

\begin{abstract}
Coronavirus (CoV) is included in severe acute respiratory syndrome (SARS). Coronavirus attacks all parts of the world and causes quite a number of deaths. The funeral process is required to follow the protocol of covid-19 but in fact in Indonesia many face situations where the forced pick-up of bodies is unexpected or confirmed covid-19 by family or local residents. One of the social problems that arise is the forced collection of the body of Covid-19 by the community without paying attention to safety and health protocols. This is dangerous because it can be a source of the spread of COVID-19. This research discusses various violations of the law due to the forcible collection of the body of Covid-19 and the forms of Criminal Liability in Collecting Covid-19 bodies. This research is a qualitative research with literature review that uses 3 kinds of approaches, namely: statute approach, conceptual approach, and case approach. The results of this study reveal that the number of cases of forced pick-up of the bodies of suspected or confirmed covid resulted in the Indonesian National Police issuing a telegram letter to the National Police Chief Number ST / 1618 / VI / Ops.2 / 2020 dated June 5, 2020. Unscrupulous individuals either in groups or individually forcing to take the body of a suspect or confirmed that Covid will be charged with multiple articles, namely; Article 214 KUHP jo, Article 335 KUHP jo, Article 336 KUHP jo, article 93 Law Number 6 Year 2018, whose information has been mentioned in the discussion.
\end{abstract}

Keywords: Covid-19, criminal, corpse, forced pick-up

\begin{abstract}
ABSTRAK
Coronavirus (CoV) termasuk ke dalam sindrom pernapasan akut parah (SARS). Coronavirus menyerang seluruh belahan dunia dan menyebabkan cukup banyak kematian. Proses pemakaman jenazah diwajibkan untuk mengikuti protokol covid-19 namun pada kenyataanya di Indonesia banyak menghadapi situasi di mana penjemputan paksa jenazah terduga atau terkonfirmasi covid-19 oleh keluarga atau warga sekitar. Salah satu permasalahan sosial yang muncul adalah penjemputan paksa jenazah covid-19 oleh masyarakat tanpa memperhatikan protokol keselamatan dan kesehatan. Hal ini menjadi berbahaya dikarenakan dapat menjadi sumber penyebaran COVID-19. Penelitian ini membahas mengenai berbagai pelanggaran undang-undang akibat penjemputan paksa jenazah covid-19 serta bentuk Pertanggungjawaban Pidana Dalam Pengambilan Jenazah Covid-19. Penelitian ini merupakan penelitian kualitatif dengan telaah pustaka yang menggunakan 3 macam pendekatan yaitu: statuta approach, conceptual approach, dan case approach. Hasil penelitian ini mengungkapkan banyaknya kasus penjemputan paksa jenazah terduga atau terkonfirmasi covid mengakibatkan pihak Kepolisian Republik Indonesia mengeluarkan surat telegram Kapolri Nomor ST/1618/VI/Ops.2/2020 tanggal 5 Juni 2020. Oknum-oknum yang dengan sengaja baik secara berkelompok maupun individu memaksa mengambil jenazah terduga atau terkonfirmasi covid akan dijerat dengan pasal berlapis yaitu; pasal 214 KUHP jo, Pasal 335 KUHP jo, Pasal 336 KUHP jo, pasal 93 UU Nomor 6 Tahun 2018, yang keterangan nya telah disebutkan dalam pembahasan.
\end{abstract}

Kata Kunci: Covid-19, pidana, jenazah, penjemputan paksa 


\section{PENDAHULUAN}

\section{Latar Belakang}

Coronavirus merupakan patogen yang menyerang sistem pernapasan manusia. Virus korona (CoV) termasuk sindrom pernapasan akut parah (SARS) -CoV dan Sindrom pernapasan Timur Tengah (MERS) - CoV yang ditandai dengan jelas sebagai agen yang merupakan ancaman kesehatan masyarakat luas. Pada akhir bulan Desember 2019, sekawanan orang dirawat di rumah sakit dengan diagnosis masuk pneumonia yang etiologinya tidak diketahui. Secara epidemiologis orang dirawat tersebut kontak erat dengan makanan laut dan hewan di pasar grosir di Wuhan, Provinsi Hubei, China (Bogoch et al., 2020).

Kronologi kasus corona sebagai berikut; mulai 18 hingga 29 Desember 2019, 5 orang dirawat di rumah sakit dengan keluhan gangguan pernapasan, 1 diantara mereka meninggal dunia (Ren et al., 2020). Pada 2 Januari 2020, sebanyak 41 orang dirawat di rumah sakit sudah teridentifikasi COVID-19 melalui pemeriksaan laboratorium, lebih kurang setengah dari jumlah orang yang dirawat mempunyai penyakit penyerta, seperti diabetes, hipertensi, dan penyakit jantung (Huang et al., 2020). Badan Komisi Kesehatan Nasional China melaporkan rincian 17 kematian pertama hingga 22 Januari, 2020. Pada 25 Januari 2020, sebanyak 1975 kasus terkonfirmasi COVID-19 di daratan China dengan total 56 kematian (Wang et al., 2020). Per 30 Januari 2020, 7734 kasus terkonfirmasi di China dan 90 kasus lainnya dilaporkan berasal dari sejumlah negara termasuk Taiwan, Thailand,Vietnam, Malaysia, Nepal, Sri Lanka, Kamboja, Jepang, Singapura, Republik Korea, Uni Emirat Arab, Amerika Serikat, The Philippines, India, Australia, Kanada, Finlandia, Prancis, dan Jerman. Tingkat kematian kasus dihitung menjadi 2,2\% (170/7824) (Bassetti et al., 2020).

Negara Indonesia, pada 2 Maret 2020 mengumumkan 2 kasus pertama covid-19 (Pranita, 2020). Hingga 21 September 2020 tercatat sebanyak 248,852 kasus terkonfirmasi dengan penambahan 4,176 kasus, sebanyak 58,378 kasus aktif (23.5\%), sebanyak 180,797 kasus sembuh (72.7\%), dan sebanyak 9,677 kasus meninggal (3.9\%), dengan rerata 2,142 kasus meninggal per harinya di bulan Agustus 2020 (Kementerian Kesehatan, 2020).

Pasien covid-19 yang telah meninggal dunia, untuk proses pemakaman jenazah diwajibkan untuk mengikuti protokol covid-19 namun pada kenyataanya di Indonesia banyak menghadapi situasi di mana penjemputan paksa jenazah terduga atau terkonfirmasi covid-19 oleh keluarga atau warga sekitar. Untuk menghadapi situasi seperti ini dari pihak yang berwajib akan memberikan sanksi tegas melalui proses hukum yang berlaku terhadap kelompok maupun individu yang terlibat dalam proses penjemputan paksa jenazah covid-19. Untuk itu dapat disimpulkan bahwa tujuan tindak pidana secara umum adalah menghilangkan tindak kejahatan secara represif yang merupakan ciri teori absolut dan menghindari tindak pidana kejahatan secara preventif yang merupakan ciri teori relative (Hattu, 2020). Sebagai contoh kasus penjemputan paksa jenazah covid-19 di RSUD Dadi Makassar tanggal 10 juni 2020, tim gabungan TNI-Polri mengamankan 3 orang guna pemeriksaan lanjutan (Amindoni, 2020).

Berkaitan dengan tindak pidana penjemputan paksa jenazah covid-19, dapat diberlakukan pasal berlapis yaitu pasal 214 KUHP jo, Pasal 335 KUHP jo, Pasal 336 KUHP jo, pasal 93 UU Nomor 6 Tahun 2018. Serta pejabat polisi Indonesia mengelurkan Telegram Kapolri No.ST/1618/VI/OPS.2/2020 Tanggal 5 Juni 2020 untuk memberikan rasa jera kepada oknumoknum yang menjemput paksa jenazah covid-19 (Yazid, 2020). Makalah ini ditulis untuk membahas mengenai berbagai aspek hukum yang dilanggar dalam penjemputan paksa jenazah covid-19. 
Tulisan ini menguraikan mengenai bagaimana aspek hukum dan bentuk pertanggungjawaban pidana pada kasus-kasus pengambilan paksa jenazah yang terinfeksi Covid-19

\section{METODE PENELITIAN}

Penelitian ini berbasis telaah pustaka dengan waktu penelitian antara tanggal 20 September 2020 hingga 25 September 2020. Pencarian data menggunakan berbagai sumber data sekunder di berbagai search engine seperti Google Scholar. Kata kunci yang digunakan adalah berupa [["Hukum" OR "Tinjauan Yuridis"]] AND ["COVID-19"] AND ["Jenazah"]. Metode penelitian yang digunakan oleh peneliti berupa Tinjauan Hukum Normatif, yang terfokus pada kajian penerapan nilai-nilai dalam hukum positif dengan menganalisis peraturan yang terkait dengan penjemputan paksa jenazah COVID-19 di Indonesia menggunakan 3 macam pendekatan yaitu: statuta approach, conceptual approach, dan case approach. Sumber data sekunder dalam penelitian ini meliputi buku, jurnal, dokumen dan lainnya. Bahan hukum sekunder adalah perundang-undangan yang berlaku, teori, doktrin, dan pendapat para ahli terkait (Ibrahim 2006)

\section{HASIL DAN PEMBAHASAN}

\section{Covid-19}

Seseorang yang terpapar dengan virus covid-19 ini akan mengalami gejala dari ringan hingga kematian pada hari ke-6 hingga hari ke-41 dengan rerata sekitar hari ke-14. Durasi waktu ini bergantung pada berbagai faktor salah satunya adalah usia dan kekebalan sistem imun orang tersebut (Wang et al., 2020). Gejala yang timbul dapat digolongkan menjadi dua, yaitu gejala sistemik dan gejala respiratorik. Gejala sistemik berupa demam, batuk dan kelelahan, produksi sputum, kepala-nyeri, hemoptisis, acute cardiac injury, hipoksemia, dispnea, limfopenia, dan diare. Sedangkan gejala respiratorik berupa rhinorrhoea, bersin dan sakit tenggorokan, pneumonia, RNAaemia, dan acute respiratory distress syndrome. Pada pemeriksaan penunjang radiologi berupa foto rontgen dada ditemukan infiltrasi di lobus atas paru-paru yang dikaitkan dengan peningkatan dispnea dengan hipoksemia, pada CT-scan dada ditemukan bilateral groundglass opacities (Lei et al., 2020).

Orang yang terinfeksi COVID-19 menunjukkan angka leukosit yang lebih tinggi, temuan pernapasan abnormal, dan peningkatan kadar plasma sitokin pro-inflamasi. Salah satu laporan kasus COVID-19 memperlihatkan bahwa pada 5 hari demam datang dengan batuk, suara kasar pada paru-paru, dan suhu tubuh $39,0^{\circ} \mathrm{C}$. Dahak orang tersebut menunjukkan positive real-time polymerase chain reaction yang mengkonfirmasi infeksi COVID-19. Studi laboratorium menunjukkan leukopenia dengan jumlah leukosit 2,91 × $10^{\wedge} 9 \mathrm{sel} / \mathrm{L}$ diantaranya $70,0 \%$ adalah neutrofil. Selain itu, juga ditemukan nilai darah $16,16 \mathrm{mg} / \mathrm{L}$ pada protein C-reaktif berada di atas kisaran normal (0-10 mg/L). Tingkat sedimentasi eritrosit tinggi dan D-dimer juga diamati (Lei et al., 2020).

\section{Aspek hukum pertanggungjawaban pidana dalam pengambilan jenazah covid-19}

Sebagaimana yang diketahui bahwa infeksi covid-19 dapat menimbulkan kematian pada orang yang terinfeksi, walaupun tidak semua orang yang terinfeksi akan berakhir pada kematian. Mayoritas penduduk Indonesia beragama muslim, saat seseorang meninggal dunia maka sudah selayaknya akan segera dikebumikan. Keluarga yang ditinggalkan akan meminta jenazah keluarganya untuk melakukan proses pemakaman, tetapi bila jenazah tersebut merupakan pasien terduga atau terkonfirmasi covid-19 maka untuk proses pemakaman jenazah mengikuti aturan penanganan covid-19. 
Pada pelaksanaannya seringkali dijumpai penjemputan paksa jenazah terduga atau terkonfirmasi covid-19 yang dilakukan oleh oknum-oknum tertentu. Hingga berita ini tersebar luas dan viral di media massa. Perlu diketahui bahwa setelah meninggal penyebaran virus covid-19 tidak berhenti, inilah alasan mengapa diperlukan panduan penanganan jenazah-19.

Negara Indonesia memiliki UU No. 4 Tahun 1984 tentang wabah penyakit menular, sebagaimana dimaksud pada pasal 5 dapat disimpulkan bahwa penanganan jenazah akibat wabah merupakan satu diantara penanggulangan wabah, dan pada pasal 14 dapat disimpulkan bahwa siapapun yang dengan sengaja menghambat pelaksanaan penanggulangan wabah, diancam dengan pidana 1 tahun dan denda 1 juta rupiah, serta merupakan suatu tindak pidana.

Penerapan hukum pidana kepada oknum penjemputan paksa jenazah terduga atau terkonfirmasi covid-19, berkaitan pertanggungjawaban dalam sifat tercela dari tindak pidana ini disesuaikan dengan peran atau kontribusi oknum dalam membuat tindak pidana. Penegak hukum dapat menjerat oknum penjemputan paksa jenazah terduga atau terkonfirmasi covid-19 dengan KUHP, UU No. 6 Tahun 2018 tentang Karantina Kesehatan

\section{KUHP}

- Pasal 214: (1) ancaman pidana penjara 7 tahun bagi orang yang berkelompok melakukan suatu paksaan dan perlawanan berdasarkan 211 dan 212

- Pasal 211: ancaman pidana 4 tahun untuk siapapun yang mengancam dengan/tanpa kekerasan kepada pejabat agar melakukan atau tidak melakukan perbuatan sesuai jabatan yang sah - $\quad$ Pasal 212: ancaman pidana 1 tahuhn 4 bulan atau denda Rp. 4.500,- kepada siapapun yang melakukan ancaman dengan/tanpa kekerasan melakukan perlawanan terhadap tugas sah seorang pejabat

- Pasal 335: (1) butir 1 siapapun yang membuat, tidak membuat, atau membiarkan sesuatu dengan/tanpa ancaman melakukan kekerasan, atau perlakuan seenaknya, baik kepada orang itu atau orang lain; butir 2 siapapun dengan menggunakan ancaman pencemaran secara lisan/tertulis memaksa tindakan, tidak melakukan tindakan, atau membiarkan tindakan, akan diancam dengan pidana penjara 1 tahun atau denda $\mathrm{Rp} 4.500$,-. (2) sesuai dengan butir 2 kejahatan hanya bisa dituntut atas pengaduan

- Pasal 336: (1) siapapun mengancam menggunakan kekerasan kepada orang/barang didepan umum dengan tenaga bersama dan membahayakan orang/barang dengan kelakuan yang melanggar kesusilaan, dengan Tindakan membahayakan nyawa, dan penganiayaan/pembakaran akan diancam pidana penjara 2 tahun 8 bulan. (2) jika tindak ancaman dilakukan secara tertulis maka akan diancam dengan pidana penjara 5 tahun

2. UU No. 6 Tahun 2018 tentang Karantina Kesehatan

- $\quad$ Pasal 93: siapapun yang melanggar penyelenggaraan karantina kesehatan seperti pasal 9 (1) dan/atau mempersulit penyelenggaran karantina kesehatan yang mengakibatkan keadaan darurat kesehatan masyarakat diancam dengan pidana penjara 1 tahun dan denda Rp 100.000.000,-

Kemudian tidak tertinggal juga pihak Kepolisian Republik Indonesia mengeluarkan surat telegram Kapolri Nomor ST/1618/VI/Ops.2/2020 tanggal 5 Juni 2020. Surat ini diperuntukan kepada kepala satuan tugas, Kasubsatgas, kepala operasi terpusat tingkat polda, dan kepala operasiter pusat tingkat polres Aman Nusa II 2020 untuk saling berhubungan dengan RS rujukan covid-19 guna memastikan dengan sebenar-benarnya penyebab kematian pasien agar dapat dilaksanakannya tata aturan penanganan jenazah covid-19 (Rahmat \& Simbolon, 2020).

Menurut Koeswadji tujuan pemidanaan adalah untuk menjaga agar masyarakat tertib, menggantikan kerugian masyarakat, membuat oknum kejahatan menyadari kesalahan dan memperbaiki sikap agar tidak terulang lagi tindak kejahatan, dan menangkap semua oknum yang 
melakukan tindak pidana (Koeswadji, 1995). Kemudian menurut Sholehuddin diberikan sanksi pidana yaitu untuk membuat jera oknum yang terpidana dan sebagai penangkal agar masyarakat tidak mencontoh perbuatan yang serupa, merehabilitasi secara sosial dan moral para oknum pidana, serta oknum tersebut dapat mengakui kesalahannya yang diperbuat dan mempertanggung jawabkannya (Sholehuddin, 2003).

\section{KESIMPULAN DAN SARAN}

Maraknya kasus penjemputan paksa jenazah terduga atau terkonfirmasi covid mengakibatkan pihak Kepolisian Republik Indonesia mengeluarkan surat telegram Kapolri Nomor ST/1618/VI/Ops.2/2020 tanggal 5 Juni 2020. Oknum-oknum yang dengan sengaja baik secara berkelompok maupun individu memaksa mengambil jenazah terduga atau terkonfirmasi covid akan dijerat dengan pasal berlapis yaitu; pasal 214 KUHP jo, Pasal 335 KUHP jo, Pasal 336 KUHP jo, pasal 93 UU Nomor 6 Tahun 2018, yang keterangan nya telah disebutkan dalam pembahasan.

\section{Ucapan Terima Kasih (Acknowledgement)}

Terima kasih kepada semua pihak yang berpartisipasi dalam penelitian ini. Terima kasih juga kepada semua pihak yang telah memberikan dukungan terhadap penelitian ini.

\section{REFERENSI}

Amindoni, A. (2020, Juni 29). Pengambilan paksa jenazah PDP covid-19: Bisa dibayangkan bagaimana sakitnya sanksi sosial yang kami dapatkan. BBC News Indonesia. https://www.bbc.com/indonesia/indonesia-53009450.

Bassetti, M., Vena, A., \& Giacobbe, D. R. (2020). The novel Chinese coronavirus (2019-nCoV) infections: Challenges for fighting the storm.European Journal of Clinical Investigation. 50(3), 1-4. https://doi.org/10.1111/eci.13209.

Bogoch, I. I., Watts, A., Thomas-Bachli, A., Huber, C., Kraemer, M. U., \& Khan, K. (2020). Pneumonia of unknown aetiology in Wuhan, China: potential for international spread via commercial air travel. Journal of Travel Medicine. 27(2), https://doi.org/10.1093/jtm/taaa008.

Handoko, D. (2018). Kitab undang-undang hukum pidana. Hawa dan AHWA.

Hattu, J. (2020). Pertanggungjawaban pidana pengambilan jenasah covid-19 secara paksa berdasarkan aturan tindak pidana umum dan tindak pidana khusus. Jurnal Belo, 6(1, 1131. https://doi.org/10.30598/belovol6issue1page11-31.

Huang, C., Wang, Y., Li, X., Ren, L., Zhao, J., Hu, Y., ... \& Cao, B. (2020). Clinical features of patients infected with 2019 novel coronavirus in Wuhan, China. The Lancet, 395(10223), 497-506. https://doi.org/10.1016/S0140-6736(20)30183-5.

Kementerian Kesehatan. (2020). Peta Sebaran. Satuan Tugas Penanganan COVID-19. https://covid19.go.id/peta-sebaran.

Koeswadji, H. H. (1995). Perkembangan Macam-Macam Pidana Dalam Rangka Pembangunan Hukum Pidana. Citra Aditya Bhakti.

Lei, J., Li, J., Li, X., \& Qi, X. (2020). CT imaging of the 2019 novel coronavirus (2019-NCoV) pneumonia. Radiology, 295(1), 18-18. https://doi.org/10.1148/radiol.2020200236.

Pranita, E. (2020, Mei 11). Diumumkan awal Maret, ahli: Virus corona masuk Indonesia dari Januari. https://www.kompas.com/sains/read/2020/05/11/130600623/diumumkan-awal-maretahli--virus-corona-masuk-indonesia-dari-januari. 
Rahmat, A., \& Foe P. S. (2020, Juni 9). Kapolri terbitkan telegram soal jenazah PDP diambil paksa keluarga. VIVA.Co.Id, https://www.viva.co.id/berita/nasional/1278684-kapolri-terbitkantelegram-soal-jenazah-pdp-diambil-paksa-keluarga?medium=autonext.

Ren, L. L., Wang, Y. M., Wu, Z. Q., Xiang, Z. C., Guo, L., Xu, T., ... \& Wang, J. W. (2020). Identification of a novel coronavirus causing severe pneumonia in human. Chinese Medical Journal, 133(9), 1015-24. https://doi.org/10.1097/CM9.0000000000000722.

Sholehuddin, M. (2003). Sistem Sanksi Dalam Hukum Pidana, Ide Dasar Double Track System Dan Implementasinya. Raja Grafindo.

Undang-Undang Nomor 4 Tahun 1984. 4. (Indonesia).

Undang-Undang Nomor 6 Tahun 2018. 6. (Indonesia).

Wang, W., Tang, J., \& Wei, F. (2020). Updated understanding of the outbreak of 2019 novel coronavirus (2019-nCoV) in Wuhan, China. Journal of Medical Virology, 92(4), 441-447. https://doi.org/10.1002/jmv.25689.

Yazid, F. (2020). Penerapan sanksi pidana terhadap pengambilan paksa jenasah pasien covid-19 di Indonesia. Jurnal Belo, 6(1), 60-72. https://doi.org/10.30598/belovol6issue1 page60-72. 